\title{
Endemic Vascular Plants of Marble and Serpentine Parent Materials in Semiarid Grassland
}

\author{
Melda Dölarslan ${ }^{1}$, Ebru Gül ${ }^{2}$, Sabit Erşahin ${ }^{2}$ \\ ${ }^{1}$ Department of Biology, Faculty of Science, Çankırı Karatekin University, 18100 Çankırı, Turkey \\ ${ }^{2}$ Department of Forestry Engineering, Faculty of Forestry, Çankırl Karatekin University, 18100 Çankırı, Turkey
}

\section{A R T I C L E I N F O}

\section{Research Articles}

Received 21 November 2017

Accepted 25 April 2018

Keywords:

Endemic plants

Metamorphic rocks

Marble

Serpentine

A4

Turkey

${ }^{*}$ Corresponding Author: E-mail: mld@karatekin.edu.tr

\section{A B S T R A C T}

Endemism is an important criterion for identification of floristic regions and determination of floristic properties of these regions. Turkey is one of the world's major countries in terms of endemism over 3.000 endemic plant species. This study was carried out in order to determine the floristic composition and endemic plant species on the serpentine and marble (metamorphic rocks) parent material in semi-arid garssland in Çankır1-Eldivan. For this reason plant samples were collected in different growing season in 2014 (month of between April- September), approximately 4ha (Marble, 3.88 ha; Serpentine, 0.08 ha) area in Çankırı-Eldivan. Study area is located A4 square according to the grid system of P.H. Davis (1965-1988) and Irano-Turanian region in phytogeographic respect. As a result of the plant sampling carried out in the area; 16 families, 27 genera, 31 species determined in serpentine parent material. Among of these plants 9 of them are endemic plant. Endemism rate of the serpentine area is $29 \%$. In addition, 20 families, 58 genera, 72 species of plants have been identified in marble parent material and 14 plant taxa of these species endemic. Endemism ratio is $19 \%$. Results of this study showed that parent material effects of plant diversity and endemism ratio.

Türk Tarım - Gıda Bilim ve Teknoloji Dergisi, 6(6): 693-698, 2018

\section{Yarıkurak Meralarda Bulunan Mermer ve Serpantin Ana Materyalinin Endemik Vasküler Bitkileri}

M A K A L E B İ L G İ S İ

AraştırmaMakalesi

Geliş 21 Kasım 2017

Kabul 25 Nisan 2018

\section{Anahtar Kelimeler:}

Endemik bitkiler

Metamorfik kayaçlar

Mermer

Serpantin

A4

Türkiye

"Sorumlu Yazar:

E-mail: mld@karatekin.edu.tr

\section{Ö Z E T}

Endemizm, floristik bölgelerin tanımlanması ve bu bölgelerin floristik özelliklerinin belirlenmesi için önemli bir kriterdir. Türkiye, 3.000'den fazla endemik bitki türü ile endemizm açısından dünyanın en büyük ülkelerinden biridir. Bu çalışma, ÇankırıEldivan'da yarı kurak meralarda serpantin ve mermer (metamorfik kayaçlar) anamateryali üzerinde gelişen floristik kompozisyonun ve endemik bitki türlerinin belirlenmesi amaciyla yürütülmüştür. Bu kapsamda, bitki örnekleri 2014 yılı vejetasyon süresi içinde farklı dönemlerde (Nisan-Eylül ayları arasında) Çankırı-Eldivan'da yaklaşık 4 ha (Mermer (3,88 ha), Serpantin (0,08 ha)) alanda toplanmıştır. Çalışma alanı, P.H. Davis (1965-1985) grid sistemine göre A4 karesindedir ve İran-Turan fitocoğrafik Bölgesindedir. Alanda yapılan bitki örneklemesi sonucunda; serpantin ana materyalinde 16 familya, 27 cins ve 31 tür tespit edilmiştir. Bu bitkilerden 9'u endemik bitkidir. Serpantinli alanının endemizm oran $1 \% 29$ 'dur. Buna ek olarak, mermer ana materyalinde ise 20 familya, 58 cins ve 72 bitki türü ve bu türlerin 14'nün endemik bitki taksonu olduğu tespit edilmiştir. Endemizm oranı \%19'dur. Bu çalışmanın sonuçları, ana materyalin bitki çeşitliliği ve endemizm oranının etkilerini göstermiştir. 


\section{Introduction}

The continual rapid population growth, industrialization and the increase in demand for natural resources hereby have become a threat for living and nonliving resources that a country can have. The destruction in the living resources that are of great importance for the country causes impairment in the ecologic balance and decrease in the biological diversity. It is known that more than 1.7 million plant and animal species have been defined in the world and Turkey is among the richest countries in Europe and the Middle East in terms of biological diversity.

According to the $10^{\text {th }}$ volume of the work entitled "Flora of Turkey and the East Aegean Islands" published by P.H. Davis, there are 8575 plant species in Turkey. 2651 of them are endemic. The ratio of endemism is $30.9 \%$ (Davis, 1965-1988). According to the results of the studies after the year two thousand, the number of taxa has reached to 12000 increasingly with the definition of new species and subspecies. 2991 (2941 of them are from Turkey and 50 of them are from the East Aegean Islands) of these plants are endemic. The ratio of endemic taxa of the total plant taxa in Turkey (endemism) is $34.4 \%$ (Ekim et al., 2000; Güner et al., 2000; Erik and Tarıkahya, 2004, Özhatay and Kültür, 2006; Özhatay et al., 2011; Güner et al., 2012). Mediterranean and Eastern Anatolia are the richest regions in terms of endemic plant (Erik and Tarıkahya, 2004). These regions are followed by Central Anatolia, Black Sea, Aegean, Marmara and Southeast Anatolia respectively (Uyanık et al., 2013).

Among the factors which are effective in Turkey's having rich plant diversity are the climate of Turkey, its geographical location, Turkey's being a peninsula and its geomorphological structure (I.e. The mountains extend parallel along the shore, high mountainous areas). At the same time, different climate type, parent material and soil characteristics also affect the vegetation, accordingly the rate of endemism.

In line with this, the purpose of this paper is twofold: (1) to determinate of floristic composition of vascular plant species grown on marble and serpentine parent material and (2) to compare of the endemism rates of vascular plant species growing in the soil formed on the marble and serpentine parent material which are different metamorphic rocks. In short, this paper undertakes to evaluate how the metamorphic rocks impact the endemism rates of vascular plant species in semiarid grassland. In this context, there is a linear relation between parent material and endemism. This study was carried out determination of endemic plant growth on different serpentine and marble parent material in semiarid grassland in Çankırı-Eldivan.

\section{Material and Methods}

\section{Study Area}

The study area is Eldivan country, which is affiliated to Çankırı province and located in the southeast of the province in central K1z1lırmak District of Central Anatolia Region. Its location is between $40^{\circ} 34^{\prime} 41^{\prime \prime}-40^{\circ} 20^{\prime} 38^{\prime \prime}$ north latitude and $33^{\circ} 36^{\prime} 00^{\prime \prime}-33^{\circ} 25^{\prime} 10^{\prime \prime}$ east longitude (Figure 1). The country is located in the Çankırı G31-d4 and G30-c3 map sections on a topographical map with a $1 / 25000$ scale. The marble parent material takes up 3.88 ha and the serpentine parent material takes up 0.08 ha in the study area (Figure 1).

According to the meteorological data (18 years of climatic data 1989-2007) about Eldivan District, the mean annual temperatures $10^{\circ} \mathrm{C}$, the mean monthly average ranging from $1^{\circ} \mathrm{C}$ (January) to $2^{\circ} \mathrm{C}$ (July-August). The average annual precipitation is $496 \mathrm{~mm}$, with the maximum monthly precipitation $(53 \mathrm{~mm})$ in December and the minimum (21 mm) in July (Anonymous, 2007).

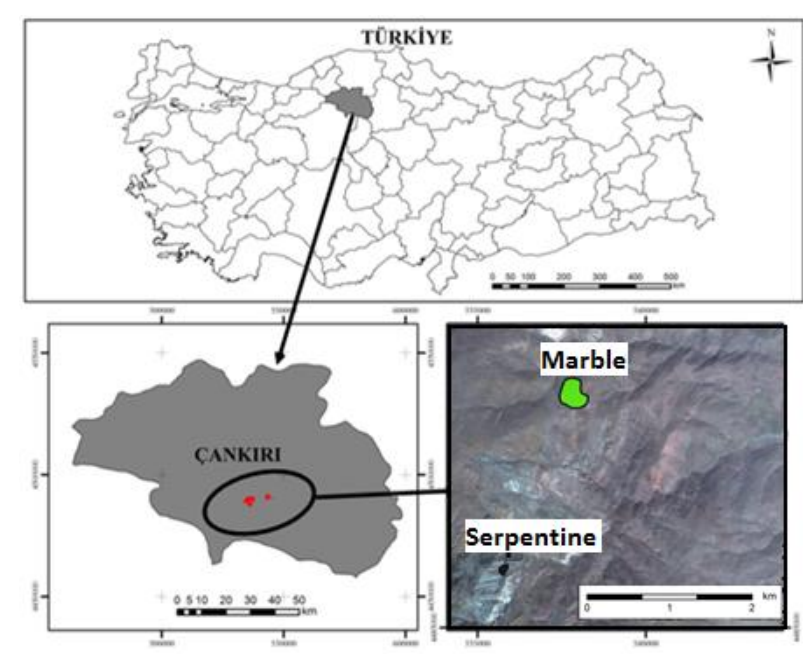

Fig 1Map of the study area

\section{Plant Sampling}

Study area is located A4 square according to the grid system of P.H. Davis (1965-1985) and Iranian-Turan region in phytogeographic respect. Plant samples were collected and recorded periodically from April to September (the vegetation period) in 2014 in approximately 4ha (Marble, 3.88 ha; Serpentine, 0.08 ha) area in Çankırı-Eldivan.

It has been noted that plant samples are robust, their leaves are full, their flowers are open and undamaged, their fruits and seeds are mature. From each plant species at least two pairs of samples were taken and they were placed in the Herbarium of the Faculty of Science of Çankırı Karatekin University after being identified. Komarov (1978), Bor et al. (1969) and particularly the work of "The Flora of Turkey and Eastern Aegean Islands (Davis, 1965-1988)" were used in recognition of the samples of the plants.

\section{Results}

As a result of the identification of plant samples, which were collected and recorded periodically from April to September (the vegetation period) in 2014 to evaluate the flora of the region, naturally marble parent material vegetation consist of 20 families 58 genus 72 species, serpentine vegetation formed from in 16 families, 27 genus, 31 species (Table 1a,1b). 
Table 1a Floristic composition of study area

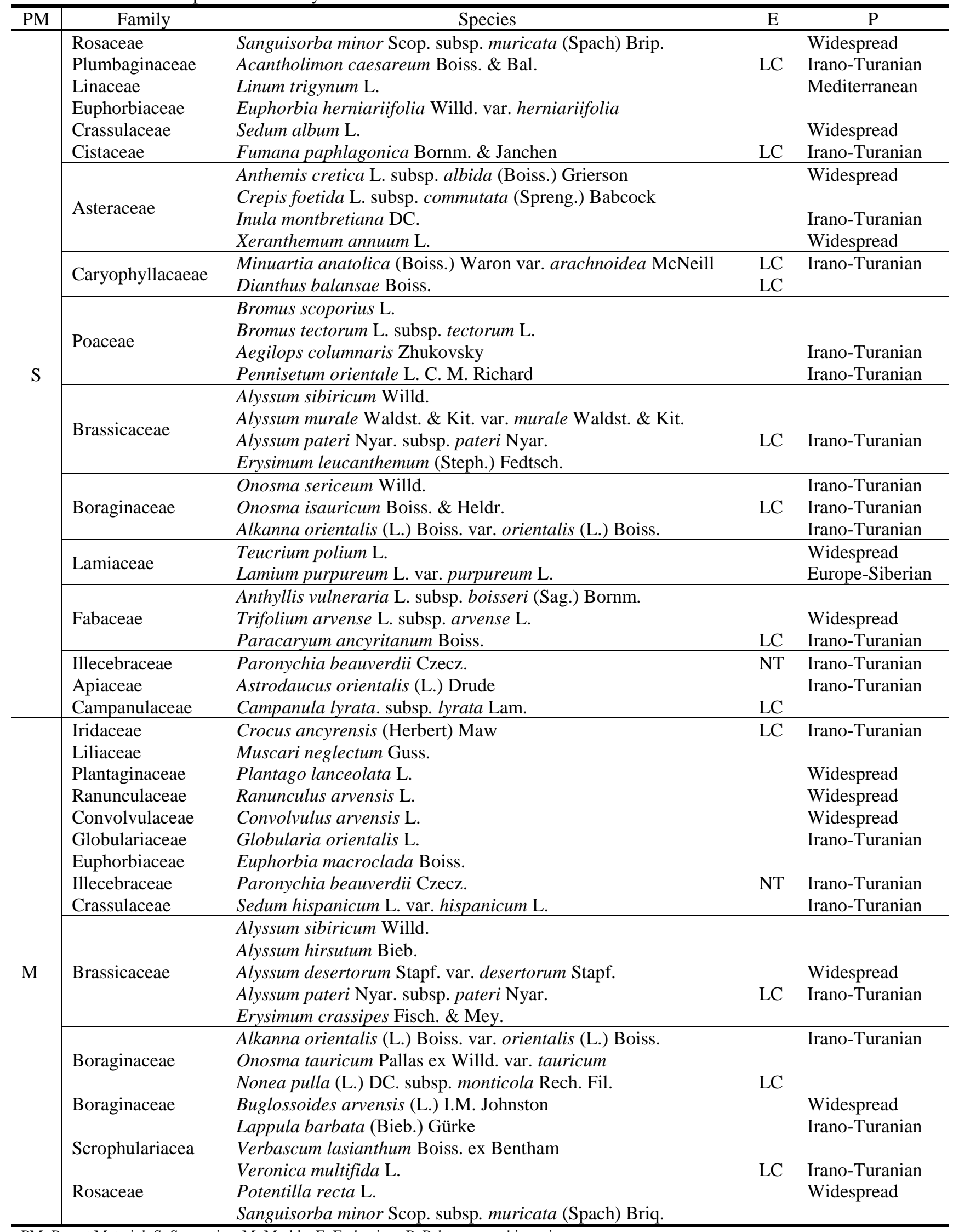

PM: Parent Material, S: Serpentine, M: Marble, E: Endemism, P: Pyhtogeographic region 
Table 1b Floristic composition of study area

\begin{tabular}{|c|c|c|c|c|}
\hline $\mathrm{PM}$ & Family & Species & $E$ & $\mathrm{P}$ \\
\hline \multirow{6}{*}{$\mathrm{M}$} & Fabaceae & $\begin{array}{l}\text { Dorycnium pentaphyllum Scop. subsp. anatolicum (Boiss.) Gams } \\
\text { Medicago lupulina L. } \\
\text { Medicago minima (L.) Bart. var. minima (L.) Bart. } \\
\text { Astragalus lydius Boiss. } \\
\text { Astragalus leucothrix Freyn \& Bornm. } \\
\text { Astragalus karamasicus Boiss. \& Bal. } \\
\text { Astragalus microcephalus Willd. } \\
\text { Onobrychis armena } \text { Boiss. \& Huet } \\
\text { Onobrychis hypargyrea Boiss. } \\
\text { Lotus aegaeus (Gris.) Boiss. }\end{array}$ & $\begin{array}{l}\text { LC } \\
\text { LC } \\
\text { LC } \\
\text { LC }\end{array}$ & $\begin{array}{l}\text { Irano-Turanian } \\
\text { Widespread } \\
\text { Irano-Turanian } \\
\text { Irano-Turanian } \\
\text { Irano-Turanian } \\
\text { Irano-Turanian }\end{array}$ \\
\hline & $\begin{array}{l}\text { Apiaceae } \\
\text { Caryophyllacaeae }\end{array}$ & $\begin{array}{l}\text { Eryngium bithynicum Boiss. } \\
\text { Dianthus zederbaueri Vierh. }\end{array}$ & $\begin{array}{l}\mathrm{LC} \\
\mathrm{LC}\end{array}$ & $\begin{array}{l}\text { Irano-Turanian } \\
\text { Irano-Turanian }\end{array}$ \\
\hline & Poaceae & $\begin{array}{l}\text { Taeniatherum caput-medusae (L.) Nevski subsp. crinitum } \\
\text { (Schreber) Melderis } \\
\text { Bromus japonicus Thunb. subsp. japonicus Thunb. } \\
\text { Bromus tectorum L. subsp. tectorum L. } \\
\text { Agrostis stolonifera L. } \\
\text { Koeleria cristata } \text { (L.) Pers. } \\
\text { Festuca valesiaca } \text { Schleich. ex Gaudin } \\
\text { Aegilops umbellulata Zhukovsky subsp. umbellulata Zhukovsky }\end{array}$ & & $\begin{array}{l}\text { Widespread } \\
\text { Europe-Siberian }\end{array}$ \\
\hline & $\begin{array}{l}\text { Poaceae } \\
\text { Plumbaginaceae }\end{array}$ & $\begin{array}{l}\text { Poa bulbosa } \mathrm{L} . \\
\text { Acantholimon caesareum Boiss. \& Bal. }\end{array}$ & LC & $\begin{array}{l}\text { Widespread } \\
\text { Irano-Turanian }\end{array}$ \\
\hline & Lamiaceae & $\begin{array}{l}\text { Salvia cryptantha Montbr \& Auch. ex Bentham } \\
\text { Salvia virgata Jacq. } \\
\text { Thymus sipyleus subsp. sipyleus } \text { var. sipyleus Boiss. } \\
\text { Stachys byzantina } \text { C. Koch } \\
\text { Teucrium polium } \text { L. } \\
\text { Sideritis montana } \text { L. subsp. montana } \text { L. } \\
\text { Nepeta nuda } \text { L. subsp. albiflora (Boiss.) Gams }\end{array}$ & $\begin{array}{l}\mathrm{LC} \\
\mathrm{LC}\end{array}$ & $\begin{array}{l}\text { Irano-Turanian } \\
\text { Irano-Turanian } \\
\text { Europe-Siberian } \\
\text { Widespread } \\
\text { Mediterranean } \\
\text { Irano-Turanian }\end{array}$ \\
\hline & Asteraceae & $\begin{array}{l}\text { Cirsium arvense (L.) Scop. subsp. vestitum (Wimmer \& Grab.) } \\
\text { Anthemis tinctoria } \text { L. var. pallida DC. } \\
\text { Anthemis tinctoria } \text { L. var. tinctoria } \text { L. } \\
\text { Anthemis triumfettii (L.) All. } \\
\text { Achillea biebersteinii Afan. } \\
\text { Crupina vulgaris Cass. } \\
\text { Leontodon asperrimus (Willd.) J. Ball } \\
\text { Scorzonera cana (var. cana (C. A. Meyer) Hoffm. } \\
\text { Tripleurospermum elongatum (Fisch. \& Mey.) Bornm. } \\
\text { Carduus nutans sensu lato } \\
\text { Centaurea solstitialis L. subsp. solstitialis L. } \\
\text { Centaurea virgata LAM. } \\
\text { Xeranthemum annuum L. } \\
\text { Echinops viscosus DC. subsp. bithynicus (Boiss.) Rech. } \\
\text { Inula oculus-christi L. }\end{array}$ & & $\begin{array}{l}\text { Widespread } \\
\text { Widespread } \\
\text { Irano-Turanian } \\
\text { Irano-Turanian }\end{array}$ \\
\hline
\end{tabular}

PM: Parent Material, S: Serpentine, M: Marble, E: Endemism, P: Pyhtogeographic region

Distribution of the species identified in the study area is examined according to the phytogeographical regions; the Irano-Turanian species of origin are in the majority. This indicates that the region is located in the IranoTuranian phytogeographic region in terms of plant phytogeography and that within the A4 grid according to the Grid system of Davis (1965). In addition, there are species belonging to the Euro-Siberian with Mediterranean phytogeographical region and phytogeographical regions are unknown or widely spread in the study area. Plant taxa distributions collected during the vegetation period in different parent material quadrats is located Table 2 on the basis of family, genus and taxa.
When Table 2 is examined, the maximum number of species is determined on the marble parent material. In this context, the plant samples collected due to the parent material in the study area 23 of them are endemic; 14 $(19 \%)$ in marble and $9(29 \%)$ endemic species in serpentine parent material. When we examine the distributions of endemic taxa according to phytogeographical regions; while there are no taxa in the Euro-Siberian and Mediterranean phytogeographical regions, the phytogeographic regions belonging to the endemic taxa of the study area include 18 taxa and phytoogeographic regions of Irano-Turanian unknown or 5 widely distributed taxa (Table 3 ). The endangered taxa 
of the subspecies of species and subspecies are classified as dangerous according to Version 2.3 published in 1994 by the IUCN Species Survival Commission "IUCN Red List Categories" (Ekim et al. 2000), a book entitled "Red Data Book of Turkish Plants" (Ekim et al. 2000). According to these changes, lc and cd subcategories of LR category are merged into LC category; The nt subcategory was also evaluated as NT category. Accordingly, the dangerous classes of endemic taxa of species and subspecies collected from the study area are rearranged according to "IUCN Red List Categories" Version 6.2 and shown in Table 1 and Table 3.
When the endemism cases of the species of the whole area collected from the research area are compared with the results of other studies conducted in the areas close to the research area, the endemism rate is calculated as $22 \%$ according to the total number of taxa determined in both research areas and it shows the highest endemism rate according to other studies. Although the size of the area in the other study areas and therefore the increase in the number of total number of taxa collected are effective in determining this ratio, this situation has been lost in our study and it has been seen that the difference of main material is effective on endemism (Table 4).

Table 2 Distribution of species detected in the study area

\begin{tabular}{l|ccc}
\hline Parent Material & Family & Genus & Taxa \\
\hline Marble & 20 & 58 & 72 \\
Serpentine & 16 & 27 & 31 \\
\hline
\end{tabular}

Table 3 Endemic taxa number, phytogeographical regions and conservation status of different parent material floristic composition (LC: Least Concern, NT: Near Threatened)

\begin{tabular}{l|clc}
\hline Parent Material & Endemic Taxa Number & Conservation status & Phytogeographical Regions \\
\hline \multirow{3}{*}{ Serpentine } & 6 & LC & Irano- Turanian (7) \\
& 1 & NT & Wide Spreead-Unknown (2) \\
\hline \multirow{3}{*}{ Marble } & 2 & It's not certain & Irano- Turanian (11) \\
& 10 & LC & Wide Spreead-Unknown (3) \\
\hline
\end{tabular}

Table 4 Comparison of the proportion of endemic plants collected from the study area with the data obtained from studies conducted near the study area

\begin{tabular}{|c|c|c|c|c|c|c|c|c|c|c|c|c|}
\hline \multirow{3}{*}{ Endemism } & \multicolumn{12}{|c|}{ Study Areas } \\
\hline & \multicolumn{2}{|c|}{1} & \multicolumn{2}{|c|}{2} & \multicolumn{2}{|c|}{3} & \multicolumn{2}{|c|}{4} & \multicolumn{2}{|c|}{5} & \multicolumn{2}{|c|}{6} \\
\hline & Taxa & $\%$ & Taxa & $\%$ & Taxa & $\%$ & Taxa & $\%$ & Taxa & $\%$ & Taxa & $\%$ \\
\hline Endemic & 23 & 22 & 63 & 18 & 62 & 15 & 35 & 9 & 31 & 12 & 31 & 9 \\
\hline
\end{tabular}

\section{Discussion and Conclusion}

According to the result of plant sampling realized on about 4 ha, two different parent materials, the floristic composition of serpentine parent material comprises of 27 genus and 31 species belonging to 16 families and the floristic composition of marble parent material comprises of 58 genus and 72 species belonging to 20 families. Within this scope, the vegetation varies in the regions which have a different parent material and soil characteristics under the same climate type.

In the study conducted by Şahin et al. (2015), sampling of the plants at 41 grasslands in Çankırı province was made. In this study, the parent material classification in these grasslands was not made, and also the endemism rate of these areas was determined as $12.8 \%$. Since the number of endemism cannot be compared with the data in the fields, use of the endemism ratio is more useful in flora studies. For instance, as it is stated by Duran (2013) that the variation in parent material and soil types has an important role in the determination of the diversity of plant communities and their spread areas. Besides, there is a close relation between the endemism ratio and the structure of the parent material. Gemici et al. (1992) stated in their study that the serpentine unified with the ultramafic rocks is remarkable in terms of endemism and also these types of rocks demonstrate spread in the important part of the districts in Anatolia. Within this scope, 23 of the plant samples gathered subject to the parent material in the study area are endemic and there are 14 endemic species in the marble parent material (metamorphic) and 9 endemic species in the serpentine (metamorphic). The populations spread on the ultramafic rocks often differ from the populations in the calcareous ranges. According to Kruckeberg (1954), this event is defined as "serpentinemorphism". The reason why the floristic composition on such kind of rocks is remarkably different and rich in terms of endemic, probably, is geological isolation. This isolation could provide the formation of new species in such kind of ranges. In their studies, Gemici et al. (1992) and according to Mason (1946a, $1946 \mathrm{~b})$, it is indicated that some of the narrow spread species on the ultramafic rocks can be called as "edaphic endemic". So, 9 of the 31 taxa determined in the serpentine parent material in the study area can be called as edaphic endemic. The literature also supports this outcome. For example, Mutlu (1995), in addition to 
Duran (2012), found high endemism number and ratio in serpentine parent material. Also, Duran (2012) indicated that the high endemism ratio is a typical feature found in all serpentine area in Turkey.

A limitation in the present study should be acknowledged. Although the rate of endemism is decisive, this study may have limited generalizability because data were collected from a limited area of marble and serpentine parent materials. Therefore, the study findings need to be validated in larger grassland areas.

\section{Acknowledgement}

This study was supported 1140707 number of The Scientific and Technological Research Council of Turkey (TUBITAK) project.

\section{References}

Anonymous. 2007. Çankırı-Eldivan Meteoroloji Bülteni. T.C. Çevre ve Orman Bakanlığı Devlet Meteoroloji İşleri Genel Müdürlüğü Kayıtları, Ankara.

Bor NL, Towsend CC, Guest E, Rawi AA. 1969. Flora of Iraq., Vol.9 Gramineae.

Davis PH. 1965-1988. Flora of Turkey and The East Aegean Islands Vol: I-X, Edinburgh University Press, United Kingdom.

Duran A, and Duman H. 1996. Dumanlı Dağı (Çankırı) Florası. Turkish Journal of Botany, 20: 143-161.

Duran A, 2012. Kızıldağ'ın Floristik Önemi. Doğa Koruma ve Milli Parklar Genel Müdürlüğü, Biyolojik Çeşitlilik Sempozyumu, Ankara.

Duran C. 2013. Türkiye'nin bitki çeşitliliğinde dağlık alanların rolü. Biyoloji Bilimleri Araştırma Dergisi, 6 (1): 72-77.

Ekim T, Koyuncu M, Vural M, Duman H, Aytaç Z, Adıgüzel N. 2000. Türkiye bitkileri kırmızı kitabı (Eğrelti ve tohumlu bitkiler), Van Yüzüncü Yıl Üniversitesi, Türkiye Tabiatını Koruma Derneği, Ankara.

Erdoğan N. 2001. Kabalı Dağı (Çerkeş/Çankırı) Florası. Ankara Üniversitesi, Fen Bilimleri Enstitüsü, Yüksek Lisans Tezi, Ankara.

Ergül N. 2000. Gürgenli Dağı Florası (Çankırı/Türkiye). Ankara Üniversitesi, Fen Bilimleri Enstitüsü, Yüksek Lisans Tezi, Ankara.
Erik S, Tarıkahya B. 2004. Türkiye florası üzerine, Kebikeç İnsan Kaynakları Araştırmaları Dergisi, 17: 139-163.

Ertuğrul G. 2011. Çankırı-Korubaşı Tepe ve Civarındaki Jipsli Alanların Florası, İstanbul Üniversitesi, Fen Bilimleri Enstitüsü, Yüksek Lisans Tezi, İstanbul.

Gemici Y, Seçmen Ö, Ekim T, Leblebici E. 1992. "Türkiye'de endemizm ve İzmir yöresinin bazı endemikleri”, Ege Coğrafya Dergisi, 6: 61-8.

Güner A, Özhatay N, Ekim T. Başer KHC. 2000. Flora of Turkey and the East Aegean Islands, Supplement II., Vol. XI., Edinburgh: Edinburgh University Press.

Güner A, Aslan S, Ekim T, Vural M. Babaç MT. 2012. Türkiye bitkileri listesi (Damarlı bitkiler). Nezahat Gökyiğit Botanik Bahçesi ve Flora Araştırmaları Derneği Yayınları, İstanbul.

IUCN. 2006. Guidelines for Using the IUCN Red List Categories and Criteria. Species Survival Commission, Version 6.2.

Kruckeberg AR. 1954. The ecology of serpentine soils III: Plant Species in Relation to Serpentine Soils, Ecology, (35): 267274.

Komarov VL. 1978. Flora of the U.S.S.R., 30 vols. and Index, Leningrad (English Translation by IPST) Jarusalem, 934.

Mason HL. 1946a. The edaphic factor in narrow endemism I: the nature of environmental influence, Mandora, 8: 209-226.

Mason HL. 1946b. "The edaphic factor in narrow endemism ii: The geographic occurrence of plants of highly restricted patterns of distribution", Mandora, 8: 241-256.

Mutlu B. 1995. Kızıldağ (Isparta) milli park1 floras1. Gazi Üniversitesi Fen bilimleri Enstitüsü, Yüksek Lisans Tezi, Ankara.

Mutlu H. 2006. Çankırı/Yapraklı ormanlarının vasküler bitkiler florası. Ankara Üniversitesi, Fen Bilimleri Enstitüsü, Yüksek Lisans Tezi, Ankara.

Özhatay N, Kültür Ş. 2006. Check-list of Additional Taxa to the Supplement Flora of Turkey III., Turkish Journal of Botany, 30: 281-316.

Özhatay N, Kültür Ş, Gürdal MB. 2011. Check-list of additional taxa to the supplement flora of Turkey. Turkish Journal of Botany, 35: 1-36.

Şahin B, Aslan S, Ünal S, Mutlu Z, Mermer A, Urla Ö, Ünal E, Özaydın KA, Avağ A, Yıldız H, Aydoğmuş O. 2015. Çankırı ili meralarının floristik özellikleri. Tarla Bitkileri Merkez Araştırma Enstitüsü Dergisi, 24 (1): 1-15.

Uyanık M, Kara ŞM, Gürbüz B, Özgen Y. 2013. Türkiye'de bitki çeşitliliği ve endemizm. Ekoloji Kongresi. 